\title{
MODERN ASSESSMENT DALAM MENYONGSONG PEMBELAJARAN ABAD 21 DAN HAMBATAN DI NEGARA BERKEMBANG
}

\author{
Rima Handayani' ${ }^{1}$, Dwi Wulandari ${ }^{2}$ \\ ${ }^{1}$ Fakultas Ekonomi dan Bisnis, Universitas Negeri Malang \\ email: handayani1821@gmail.com \\ ${ }^{2}$ Fakultas Ekonomi dan Bisnis, Universitas Negeri Malang \\ email: dwi.wulandari.fe@um.ac.id
}

\begin{abstract}
This study aims to examine more deeply the 21st century learning associated with modern assessment and examine the obstacles faced by developing countries such as Indonesia. The research method used in writing this article is literature study. The analysis technique used in writing this article is content analysis. Quizizz also contains 21st century skills, which include critical thinking skills, creative and innovative skills, communication skills, and collaborative skills. Quizizz can increase motivation which can improve critical thinking skills and creativity skills. Quizizz can also be integrated with google classrooms, so that in this case Quizizz also plays a role in improving the communication and collaboration skills of students. In addition, Quizizz can also be used to develop the character of students through honesty and self-assessment.The barrier to Quizizz in developing countries is internet access where in Indonesia not all areas are covered by the internet, especially in $3 T$ areas.
\end{abstract}

Keyword: $21^{\text {st }}$ century learning, modern assessment

\begin{abstract}
Abstrak: Studi ini bertujuan untuk mengkaji lebih dalam tentang pembelajaran abad 21 yang dikaitkan dengan modern assessment dan mengkaji hambatan yang dihadapi oleh negara berkembang seperti Indonesia. Metode penelitian yang digunakan dalam menulis artikel ini adalah studi pustaka. Teknik analisis yang digunakan dalam penulisan artikel ini adalah content analysis. Quizizz juga memuat keterampilanketerampilan abad 21, yang meliputi critical thinking skill, creative and innovative skill, communication skill, dan collaborative skill. Quizizz dapat meningkatkan motivasi dimana hal ini dapat meningkatkan keterampilan berpikir kritis dan keterampilan kreativitas. Quizizz juga dapat diintegrasikan dengan google classroom, sehingga dalam hal ini Quizizz juga berperan dalam meningkatkan keterampilan komunikasi dan kolaborasi peserta didik. Selain itu Quizizz juga dapat digunakan untuk mengembangkan karakter dari peserta didik melalui kejujuran dan penilaian diri. Hambatan Quizizz di negara berkembang adalah akses internet dimana di Indonesia tidak semua daerah terjangkau oleh internet, terutama pada daerah $3 T$.
\end{abstract}

Kata kunci: Pembelajaran abad 21, penilaian modern

\section{PENDAHULUAN}

Memasuki abad 21 menjadi sebuah tanda bahwa dunia semakin berkembang pesat dengan kemajuan teknologi yang ada. Pada abad ini memungkinkan manusia untuk melakukan segala hal yang serba digital. Begitu pula dalam mempengaruhi dinamika pendidikan baik di negara maju ataupun negara berkembang. Tidak dapat dipungkiri bahwa semua yang serba digital juga memberikan akses mudah dalam pendidikan. Jika sebelumnya pendidikan dilakukan dengan pembelajaran yang serba konvensional, maka masa sekarang 
memungkinkan pembelajaran untuk dilakukan dengan berbagai metode yang lebih modern melalui pemanfaatan teknologi digital.

Abad 21 dikenal sebagai masanya pengetahuan, maksudnya setiap hal yang berkaitan dengan pemenuhan kebutuhan hidup selalu berbasis pada pengetahuan (Yuni et al., 2016). Sistem pendidikan yang ada juga harus selalu berkembang untuk memberikan respon terhadap segala perubahan yang terjadi. Jika pada abad sebelumnya pembelajaran yang ada di lembaga pendidikan hanya berfokus pada pengetahuan saja, namun pada abad 21 ini kegiatan belajar mengajar juga harus difokuskan pada pengalaman belajar peserta didik (Chaiyo \& Nokham, 2017).

Modernisasi saat ini memungkinkan bagi guru untuk memberikan pengalaman belajar pada peserta didik dengan memanfaatkan perkembangan teknologi. Sebab, milenial saat ini lebih menyukai untuk belajar sesuatu yang lebih berguna, menyenangkan, dan juga relevan dengan apa yang mereka inginkan (Jukes \& Dosaj, 2006). Pada akhirnya hal ini menjadi sebuah tantangan baru bagi dunia pendidikan, sehingga hal ini mengharuskan pembelajaran untuk didesain dengan memperhatikan kebutuhan, preferensi, dan orientasi digital agar mencapai keberhasilan pada pembelajaran abad 21 (Prensky, 2001).

Pembelajaran abad 21 sendiri memiliki ciri dan keunikannya sendiri, dimana pembelajaran yang dilakukan di lembaga pendidikan harus berfokus pada keterampilan abad 21. Pembelajaran harus didesain sesuai dengan keterampilan 4C yang meliputi, 1) critical thinking skill (keterampilan berpikir kritis), 2) creative and innovative thinking skill (keterampilan berpikir kreatif dan inovatif), 3) communication skill (keterampilan komunikasi), dan 4) collaboration skill (keterampilan berkolaborasi) (Zubaidah, 2018). Pembelajaran pada masa ini harus didasarkan pada keempat keterampilan tersebut agar karakterisitik dalam pembelajaran abad 21 bisa tercapai. Oleh sebab itu, guru harus menyusun sebuah desain pembelajaran yang sesuai dengan keterampilan pada pembelajaran abad 21 .

Pengembangan model pembelajaran yang disesuaikan dengan pembelajaran abad 21 sangat penting untuk memberikan pengalaman belajar kepada peserta didik. Model yng digunakan juga harus meningkatkan keterlibatan peserta didik dalam pembelajaran. Sebab, pada abad ini pembelajaran tidak lagi berpusat pada guru, namun berpusat pada peserta didik. Disamping mengembangkan model pembelajaran yang lebih modern dan memuat keterampilan abad 21, guru juga harus membuat sebuah penilaian atau assessment yang lebih modern dengan memanfaatkan berbagai teknologi yang mendukung proses penilaian.

Saat ini, terdapat banyak sekali alat-alat evaluasi modern atau berbasis teknologi yang dapat digunakan oleh guru dalam rangka memberikan penilaian atau evaluasi kepada peserta didik. Hal ini tentunya dapat membuat evaluasi yang dilakukan oleh guru semakin efektif dan juga efisien. Selain itu, penggunakan alat-alat evaluasi berbasis teknologi ini juga diharapkan dapat lebih membuat peserta didik menjadi lebih rileks dalam menjalankan tes. Beberapa alat evaluasi modern berbasis teknologi yang dapat digunakan oleh guru untuk membuat kuis ataupun merekam jejak pendapat peserta didik adalah seperti kahoot, quizizz, socrative, polldaddy, verso, poll everywhere, google form, classmaker, dan lain sebagainya (Chaiyo \& Nokham, 2017). Guru dapat menggunakan alat-alat tersebut untuk menyongsong modern assessment yang lebih menarik dibandingkan dengan membuat kuis dengan kertas ataupun papan tulis yang masih konvensional, tentunya dalam menerapkan modern assessment yang berbasis teknologi ini guru juga harus memperhatikan keterampilan 4C pada pembelajaran abad 21 . Alat-alat assessment tersebut juga dapat dikembangkan untuk memberikan penilaian formatif pada peserta didik.

Studi sebelumnya menyebutkan bahwa pembelajaran dan penilaian yang berpusat pada peserta didik akan memungkin peserta didik untuk lebih partisipatif dalam pembelajaran dan berfungsi untuk 
mengembangkan pemikiran kritis, otonomi, dan juga kepercayaan diri (Hoidn, 2016). Dalam menyelenggarakan evaluasi atau penilaian tersebut, guru juga dapat menggunakan bantuan alat assessment yang berbasis teknologi seperti quizizz. Pada studi sebelumnya juga menunjukkan bahwa quizizz dapat memberikan dampak yang positif bagi pengalaman belajar peserta didik, bahkan peserta didik mendapat skor yang lebih tinggi pada evaluasi pembelajaran yang diiringi dengan tingginya skor kepuasan dari peserta didik (Zhao, 2019). Penelitian ini juga diperkuat dengan hasil penelitian lain yang menujukkan bahwa Quizizz lebih efektif dalam rangka menumbuhkan semangat belajar bagi peserta didik dibandingkan saat menggunakan Kahoot (Basuki \& Hidayati, 2019). Selain itu, Quiziz juga memberikan dampak positif dengan memberikan peningkatan hasil belajar peserta didik dan dapat mengurangi kecemasan dari peserta didik saat mengerjakan kuis yang disajikan (Aşıksoy \& Sorakin, 2018). Sebab peserta didik lebih focus dan memperhatiakan kuis saat menggunakan Quizizz (Cadieux Bolden et al., 2017). Penelitian lainnya juga menunjukkan bahwa peserta didik memiliki respon yang lebih positif dalam pembelajaran saat menggunakan Quizizz dan Kahoot dibandingkan dengan menggunakan google form (Chaiyo \& Nokham, 2017).

Pada studi sebelumnya juga ditemukan hasil bahwa Quizizz dapat digunakan untuk meminimalisir kecurangan peserta didik saat melakukan evaluasi pembelajaran (Basuki \& Hidayati, 2019). Hal ini mengartikan bahwa peran Quizizz sebagai modern assessment dalam pembelajaran tidak hanya dapat digunakan untuk meningkatkan partisipasi dan hasil belajar peserta didik saja, namun juga dapat berperan dalam pembentukan karakter peserta didik. Pada dasarenya pendidikan sendiri tidak hanya berfungsi untuk mencerdaskan manusia saja, namun peran pendidikan juga penting untuk membangun kepribadian manusia agar memiliki akhlak yang mulia (Riantoni \& Nurrahman, 2020). Selanjutnya, (Riantoni \& Nurrahman, 2020) melanjutkan bahwa pendidikan mampu diartikan sebagai sebuah usaha sadar dan juga dilakukan dengan sengaja yang bertujuan untuk mengubah tingkah laku manusia secara individu ataupun kelompok dengan tujuan untuk mendewasakannya melalui proses pelatihan dan juga pengajaran. Oleh sebab itu, penilaian melalui Quizizz ini dapat dianggap tepat dan juga mampu memberikan peran untuk dapat membangun kepribadian yang mulia bagi para peserta didik.

Studi saat ini mengasumsikan bahwa penggunaan Quizizz sebagai bentuk dari modern assessment atau penilaian yang berbasis teknologi digital sesuai dengan keterampilan yang dimaksud dalam pembelajaran abad 21. Studi sebelumnya menunjukkan efektifitas penggunaan quizizz sebagai assessment tanpa mengaitkannya dengan pembelajaran abad 21. Selain berfokus pada penggunaan Quizizz yang dikaitkan dengan abad 21, studi kali ini juga membahas permasalahan ataupun hambatan yang dihadapi oleh negara berkembang seperti Indonesia dalam menerapkan Quizizz ini sebagai bentuk dari modern assessment. Dengan demikian studi kali ini bertujuan untuk mengkaji lebi dalam tentang pembelajaran abad 21 yang dikaitkan dengan modern assessment dan mengkaji hambatan yang dihadapi oleh negara berkembang seperti Indonesia.

\section{METODE PENELITIAN}

Metode penelitian yang digunakan dalam menulis artikel ini adalah studi pustaka. Peneliti menggunakan literatureliteratur yang sebelumnya sudah ada untuk dijadikan sebagai bahan dalam menyusun artikel ini. Penelitian ini akan memberikan hasil berupa informasi yang telah disusun dalam bentuk narasi. Penyususnan artikel ini dilakukan dengan cara mengumpulkan bahan berupa literature dan hasil penelitian sebelumnya yang kemudian akan dianalisis untuk memberikan informasi yang singkat, padat, dan mudah untuk dipahami.

Teknik analisis yang digunakan dalam penulisan artikel ini adalah content analysis, dimana penulis akan membahas dengan lebih mendalam mengenai inormasi-informasi yang diperoleh melalui literature yang telah dikumpulkan sebelumnya. 


\section{HASIL DAN PEMBAHASAN}

Pembelajaran abad 21 mendukung berbagai perubahan yang berbasis teknologi di dalam dunia pendidikan. Masa ini memungkinkan pengembangan pembelajaran yang modern dengan memanfaatkan teknologi, baik pada proses belajar mengajarnya ataupun dalam proses evaluasinya. Pembelajaran abad 21 menuntut empat kerampilan yang harus menjadi karakteristik dari pembelajaran di abad ini. Keterampilan pada abad ke-21 merujuk pada banyak keterampilan, diantaranya keterampilan belajar dan inovasi seperti berpikir kritis, kreatif, kolaborasi, dan komunikasi, serta keterampilan informasi, media, dan juga teknologi (Binkley et al., 2014). Hal ini kemudian dijelaskan lebih lanjut dalam tabel 1 berikut ini.

Tabel 1. Keterampilan Abad 21 (Binkley et al., 2014)

\begin{tabular}{|c|c|}
\hline Keterampilan Abad 21 & Keterangan \\
\hline $\begin{array}{l}\text { Critical Thinking Skill } \\
\text { (Keterampilan Berpikir } \\
\text { Kritis) }\end{array}$ & $\begin{array}{l}\text { Setiap peserta didik harus mampu untuk melakukan penalaran secara efektif } \\
\text { dengan menggunakan pemikiran yang sistematis atau runtut dan melakukan } \\
\text { evaluasi terhadap sebuah informasi, memiliki kemampuan untuk } \\
\text { memecahkan permasalahan atau problem solving, dan memberikan ungkapan } \\
\text { dengan jelas }\end{array}$ \\
\hline $\begin{array}{l}\text { Creative and Innovative } \\
\text { Skill (Keterampilan untuk } \\
\text { Kreatif dan Inovatif) }\end{array}$ & $\begin{array}{l}\text { Peserta didik didorong agar memiliki kemapuan berpikir dan juga bekerja } \\
\text { secara kreatif dan inovatif, maksudnya peserta didik harus mampu } \\
\text { menciptakan ide-ide baru. Selain itu keterampilan ini juga berfokus pada } \\
\text { kemampuan untuk melihat adanya peluang }\end{array}$ \\
\hline $\begin{array}{l}\text { Communication Skill } \\
\text { (Keterampilan } \\
\text { Komunikasi) }\end{array}$ & $\begin{array}{l}\text { Keterampilan ini memungkinkan peserta didik agar mampu untuk } \\
\text { menyampaikan pemikiran ataupun ide-ide yang dimiliki, mampu melakukan } \\
\text { interaksi secara verbal, mampu melakukan komunikasi dengan berbagai } \\
\text { bentuk, dan kemampuan untuk memahami sebuah informasi yang } \\
\text { disampaikan }\end{array}$ \\
\hline $\begin{array}{l}\text { Colaborative Skill } \\
\text { (Keterampilan Kolaborasi) }\end{array}$ & $\begin{array}{l}\text { Keterampilan ini memungkinkan peserta didik untuk saling berinteraksi secara } \\
\text { efektif dengan orang lain, dengan demikian hal ini memungkinkan adanya } \\
\text { kelompok-kelompok yang memungkinkan adanya interaksi dan kerjasama. } \\
\text { Dalam kolaborasi juga dimungkinkan untuk membimbing ataupun memimpin } \\
\text { orang lain }\end{array}$ \\
\hline
\end{tabular}

\begin{abstract}
Hasil penelitian lain juga mengungkapkan bahwa sebenarnya kemampuan untuk berpikir kritis dan kreatif itu sendiri saling terkait satu sama lain. Sebab, kreativitas dan juga pemikiran kritis saling bersinggungan pada pemecahan masalah, analisa terhadap argument, dan pengambilan keputusan dimana ketiga hal ini merupakan kebiasaan berpikir yang dibutuhkan oleh peserta didik dalam untuk mengatasi permasalahan yang kompleks, menantang, dan memiliki ketiktahuan yang tinggi (Acedo \& Hughes, 2014). Saling terkait satu sama lain, nyatanya keterampilan untuk berpikir kritis dan juga kemampuan untuk saling berkomunikasi juga saling terkait. Dengan demikian apabila guru ingin mengasah
\end{abstract}

kemampuan berpikir kritis dan juga skill untuk berkomunikasi peserta didik, maka guru perlu menggunakan pendekatan yang dialogis dimana nantinya peserta didik akan didorong untuk melakukan eksplorasi terhadap ide yang dimiliki dan dapat membangun pemahamannya sendiri secara kolaboratif (Teo, 2016).

Kemjuan teknologi saat ini, komunikasi dapat dilakukan dengan sangat mudah. Bahkan seseorang bisa saling berkomunikasi walaupun berada di negara yang berbeda. Kelancaran dalam hal berkomunikasi ini juga menjadi jembatan bahwa kolaborasi tidak hanya dapat dilakukan dengan tatap muka, namun saat melakukan pembelajaran jarak jauhpun kolaborasi antar anggota kelompok 
juga dapat dilakukan. Dengan kemudahan ini, maka pembelajaran dengen car melakukan kolaborasi sebagai salah satu bentuk interaksi akan dapat meningkatkan keterlibatan dan partisipasi dari peserta didik yang mengartikan bahwa peserta didik akan dapat lebih aktif saat berkomunikasi, berpikir, dan juga belajar bersama (Teo, 2019), sehingga pengetahuan bersama akan dibentuk dengan sendirinya.

Abad 21 sangat memungkinkan bagi guru untuk melakukan assessment atau penilaian dengan cara yang lebih modern, yaitu dengan memanfaatkan teknologi sebagai alat penilaian. Quizizz menjadi salah satu alat berbasis teknologi modern yang dapat digunakan sebagai sebuah assessment yang modern, sebab Quizizz ini menuntut akses terhadap internet dan juga gadget ataupun computer. Kini, guru dapat memanfaatkan alat evaluasi berbasis web seperti Quizizz. Quizizz sendiri adalah sebuah aplikasi edukasi dengan komsep gamefication (Mac Namara \& Murphy, 2017) yang menampilkan gambar-gambar untuk mengetahui apakah jawabannya tersebut benar atau salah (Zhao, 2019) yang disuguhkan kepada peserta didik (Miller, 2016). Terdapat beberapa hal yang dapat dipertimbangkan oleh guru dalam menjadikan Quizizz sebagai salah satu alat penilaian modern atau modern assessment untuk peserta didik seperti pada table 2 berikut.

Tabel 2. Keunggulan Quizizz sebagai Modern Assessment (Orhan Göksün \& Gürsoy, 2019)

\begin{tabular}{ll}
\hline \multicolumn{1}{c}{ Kriteria } & \multicolumn{1}{c}{ Keunggulan } \\
\hline Presentasi pertanyaan & $\begin{array}{l}\text { Guru tidak perlu menyiapkan proyektor atau layar besar untuk menampilkan } \\
\text { pertanyaan dan jawaban, sebab pertanyaan dan jawaban langsung bisa diakses } \\
\text { secara individual oleh peserta didik melalui layarnya sendiri (smartphone, } \\
\text { gadget, ataupun komputer) }\end{array}$ \\
& $\begin{array}{l}\text { Peserta didik dapat melanjutkan pertanyaan setelah menjawab pertanyaan } \\
\text { sebelum waktu untuk menjawab setiap pertanyaan habis }\end{array}$ \\
Progress & $\begin{array}{l}\text { Perangkat yang dimiliki oleh peserta didik ataupun guru harus terhubung } \\
\text { dengan internet, baik itu smartphone, gadget, ataupun komputer dimana guru }\end{array}$ \\
Teknis & dapat memulai waktu kuis sementara peserta didik dapat mulai menjawabnya \\
& $\begin{array}{l}\text { Pertanyaan tidak dibatasi oleh jumlah karakter, jadi pertanyaan bisa panjang } \\
\text { ataupun pendek tanpa batasan tertentu }\end{array}$ \\
Panjang Pertanyaan & Jumlah pilihan ganda dari jawaban sangat fleksibel, bergantung pada \\
kriteria Pertanyaan dan & jawaban saja. Selain itu guru tidak hanya dapat memvisualisasikan pertanyaan \\
Jawaban & saja, tetapi juga bisa memvisualisasikan jawaban \\
& Guru dapat melakukan pratinjau saat mengembangkan pertanyaan yang akan \\
disajikan
\end{tabular}

Berdasarkan table 2, Quizizz menunjukkan bahwa tidak adanya batasan karakter yang terdapat di dalam Quizizz, sehingga hal ini akan memungkinkan guru untuk membuat soal yang sifatnya HOTS atau Higher Order Thinking Skill, agar memberikan dorongan pada peserta didik untuk berpikir secara kritis dan mendalam. Sebab, hal ini peserta akan lebih cenderung untuk mampu memecahkan sebuah permasalahan yang disajikan dan berpikir secara lebih kompleks (Dinni, 2018). Dalam hal ini guru juga dituntut untuk kreatif dalam mnyusun pertanyaan yang sifatnya HOTS, sebab kemampuan berpikir kritis sendiri harus didorong dengan pertanyaanpertanyaan yang memuat $\mathrm{C} 4$ (kognitif 4) hingga C6 (kognitif 6) sesuai yang ada dalam taksonomi Bloom. Jadi guru dapat membuat pertanyaan-pertanyaan berupa kasus, bukan lagi berupa konsep yang jawabannya sesuai dengan apa yang ada di dalam buku.

Quizizz juga memungkin guru untuk untuk menyusun pertanyaan kuis dengan jawaban panjang atau essay, jadi tidak hanya sekedar pilihan ganda. Adanya fitur untuk 
menjawab soal essay ini juga dapat memicu kreativitas peserta didik dalam menjawab soal. Soal essay sendiri dapat dipergunakan untuk mengukur keterampilan berpikir kreatif pada peserta didik.(Kristiani et al., 2017) Katakanlah jika soal tersebut memang membutuhkan jawaban yang sifatnya subyektif dari peserta didik maka Quizizz dapat menjadi solusi tanpa adanya batasan dalam pilihan jawaban yang akan membatasi kreativitas peserta didik dalam menyampaikan ide yang dimiliki. Berdasarkan hal ini, maka Quizizz sangat sesuai untuk diterapkan sebagai modern assessment pada abad 21 seperti saat ini.

Penelitian yang dilakukan oleh (Hoidn, 2016) menunjukkan bahwa penilaian yang dipusatkan pada peserta didik akan membuat peserta didik lebih partisipatif dalam pembelajaran dan juga dapat mengembangkan pemikiran kritis, otonomi, dan juga kepercayaan diri. Rasa percaya diri yang semakin tinggi juga dapat menjadikan peserta didik lebih aktif dalam kegiatan pembelajaran. Hal ini pada akhirnya dapat memicu keberanian peserta didik dalam berkomunikasi dan menyampaikan ide yang dimilikinya kepada orang lain. Selain itu dalam Quizizz, setelah peserta didik menjawab pertanyaan maka hasil skor akan langsung keluar dan peserta didik juga dapat melakukan pengecekan terhadap hasil kinerjanya, sehingga peserta didik dapat melihat jawaban yang benar dan yang salah beserta jawaban yang benar. Dengan mengetahui kesalahannya, maka hal ini akan meminimalisisr kemungkinan pada kesalahan yang sama di masa depan.

Quizizz terbukti dapat meningkatkan pengalaman belajar dan keterlibatan bagi peserta didik (Zhao, 2019). Berdasarkan hal tersebut maka, Quizizz sendiri dapat merupakan sebuah assessment yang berbasis gamification. Quizizz memberikan dampak yang sangat positif bagi pembelajaran dan juga keterlibatan peserta didik dalam pemebelajaran. Meningkatnya keterlibatan peserta didik dalam pembelajaran sendiri dipicu dengan berbagai hal, seperti Quizizz dapat meningkatkan semangat peserta didik, membuat peserta didik semakin minat dalam pembelajaran, meningkatkan konsentrasi dan fokus dari peserta didik, sehingga peserta didik tidak merasa terganggu dengan penggunaan-penggunaan elektronik lainnya, dan dapat meningkatkan motivasi peserta didik dalam pembelajaran saat pemelajaran itu sendiri berlangsung. Lebih lanjut Quizizz dipandang dapat meningkatkan berbagai hal yang ada dalam peserta didik, seperti meningkatkan konsentrasi saat mengerjakan kuis-kuis yang disajikan, mengurangi kecemasan dalam menghadapi ujian ataupun pertanyaan, meningkatkan minat peserta didik dalam pembelajaran, mengurangi gangguangangguan yang disebabkan oleh perangkat elektronik, meningkatkan hasil belajar, meningkatkan motivasi, memberikan peningkatan kepuasan dan ketertarikan peserta didik, serta mendorong peserta didik untuk berpikir dan memecahkan permsalahan dalam pertanyaan yang disajikan Quizizz (Chaiyo \& Nokham, 2017; Zhao, 2019).

Kaitan antara Quizizz dengan pembelajaran abad 21 terletak pada bagaimana Quizizz mampu meningkatkan motivasi belajar yang ada dalam peserta didik (Zhao, 2019). Motivasi yang tinggi dalam belajar akan membuat peserta didik menjadi fokus atau lebih konsentrasi dalam pembelajaran, semanagat dan minat untuk belajar, tertarik untuk mengikuti pembelajaran, belajar terasa lebih menyenangkan dan tanpa beban, serta peserta merasa puas dalam belajar. Peningkatan motivasi dari peserta didik yang terjadi nyatanya dapat mempengaruhi keterampilan berpikir kritis dan kreativitas yang mereka miliki (Rodriguez, 2009). Dorongan motivasi peserta didik dalam belajar akan dapat meningkatkan kreativitas dan critical thinking dari peserta didik itu sendiri (Howard et al., 2015). Dimana critical thinking yang dimaksudkan dalam hal ini adalah peserta didik akan dapat menyelesaikan sebuah permasalahan ataupun pertanyaan yang disajikan dalam kuis serta mampu untuk kreatif dalam memunculkan ide dari permasalahan yang disajikan.

Selain memberikan dampak yang positif pada keterlibatan peserta didik dalam pembelajaran, nyatanya Quizizz juga dapat membuat peserta didik semakin tertarik dalam mengikuti kuis, sebab Quizizz dianggap lebih menyenangkan dan membuat ketagihan, suasana pembelajaran lebih 
energik, membuat peserta didik lebih percaya diri karena kecil kemungkinan untuk melakukan kecurangan membuat peserta didik lebih mandiri, meme yang terdapat dalam fitur Quizizz juga membuat peserta menjadi terhibur, dan memacu semangat peserta didik untuk mnegerjakan pekerjaan rumah (Basuki \& Hidayati, 2019). Quizizz sendiri memang menyajikan visual yang sangat menarik, sehingga hal ini tentunya dapat mengurangi kecemasan peserta didik dalam menghadapi ujian ataupun pertanyaan. Peserta didik cenderung gugup saat memulai sebuah ujian, namun dengan visual dan meme yang disajikan oleh Quizizz maka hal ini dapat membuat peserta didik menjadi lebih rileks dalam menghadapi ujian ataupun pertanyaan yang disajikan dalam kuis. Disamping itu, Quizizz juga dapat dijadikan sebagai sebuah alat evaluasi diri, maksudnya setiap peserta didik dapat melakukan penilaian terhadap dirinya sendiri, sehingga hal ini dapat meningkatkan pemahaman yang diperoleh oleh peserta didik (Rahayu \& Purnawarman, 2019).

Berdasarkan uraian tersebut, pada dasarnya Quzizz dapat dijadikan sebagai salah satu alat assessment yang modern dan dapat mningkatkan motivasi peserta didik dalam melaksanakan kegiatan pembelajaran. Terbukti bahwa peserta didik semakin konsentrasi, semangat, focus, dan tertarik pada pembelajaran. Lalu apa kaitan antara Quizizz dengan pembelajaran abad 21? Sebab motivasi belajar dari peserta didik itu sendiri yang diiringi dengan gaya belajar turut berkontribusi dalam peningkatan keterampilan berpikir kritis (Rodriguez, 2009). Kemudian hal ini diperkuat dengan pernyataan bahwa keterampilan berpikir kritis bergantung pada kemampuan dan dan motivasi seseorang pada situasi tertentu (Howard et al., 2015). Tidak hanya memberikan efek pada peningkatan kemampuan berpikir kritis saja, namun motivasi intrinsik dari seorang peserta didik juga dapat meningkatkan kreativitas dari peserta didik itu sendiri (Howard et al., 2015).

Komunikasi dan kolaborasi dapat dilakukan dimana saja dan kapan saja. Hal ini tentunya juga berdampak positif bagi perkembangan pembelajaran, sebab walaupun dilakukan dengan jarak jauh namun komunikasi dan kolaborasi antar peserta didik tetap dapat dilakukan. Jadi dalam hal ini Quizizz mendukung kolaborasi antar tim dan juga komunikasi dengan anggota tim dalam memecahkan sebuah permasalahan ataupun pertanyaan yang disajikan di dalam kuis. Quizizz sendiri juga dapat diintegrasikan dengan Google Classroom dan google classroom sendiri dapat meningkatkan kolaborasi dan juga komunikasi (Heroza et al., 2020), sehingga jika keduanya diintegrasikan maka keterampilan kolaborasi dan komunikasi juga dapat ditingkatkan melalui Quizizz. Hal ini juga didukung oleh fitur yang ada di dalam Quizizz juga mendukung adanya kerjasama tim, artinya fitur yang ada di dalam Quizizz juga mendorong keterampilan dalam berkolaborasi dan komunikasi. Fitur ini sangat bagus dimanfaatkan apabila semua peserta didik dan guru berada dalam satu kelas dan lekukan tatap muka. dengan adanya fitur ini, maka peserta didik dapat membuat sebuah tim untuk memecahkan persoalan dalam kuis dan langsung menjawabnya. Dalam hal ini guru juga dapat melakukan pemantauan dan penilaian pada aspek-aspek lainnya seperti aspek afektif dan psikomotorik.

Berdasarkan uraian tersebut, maka keunggulan dari Quizizz yang lainnya dalam rangka menyongsong pembelajaran abad 21 adalah Quizizz ini dapat meningkatkan keterampilan komunikasi dan kolaborasi bagi peserta didik, sebab Quizizz memiliki sebuah fitur yang mendukung peserta didik untuk melakukan kolaborasi dengan teman sebayanya. Quizizz sebagai alat evaluasi dapat dengan mudah diinterpretasikan dalam pembelajaran, selain itu Quizizz juga dapat diinterpretasikan dalam google classmeet (Heroza et al., 2020). Hal inilah yang nantinya akan membantu peserta didik untuk melakukan komunikasi dan juga saling berkolaborasi dalam memecahkan pertanyaan-pertanyaan yang ada di dalam Quizizz. Jika pembelajaran dilakukan dengan metode pembelajaran jarak jauh, maka kedua aplikasi ini akan dapat membantu sekaligus guru dapat melakukan pemantauan terhadap diskusi yang dilakukan oleh peserta didik. Oleh sebab itu Quizizz ini juga dapat dijadikan sebagai salah alternatif assessment 
saat dilakukan pembelajaran secara online, terlebih lagi pada masa-masa pandemi seperti saat ini (Wahyudi et al., 2020). Jadi assessment yang dilakukan oleh guru akan lebih menarik dan menyenagkan dibandingkan harus mengerjakan soal-soal di kertas kemudia dikirimkan melalui group chatting.

Berdasarkan hal-hal tersebut, maka alat evaluasi atau assessment dengan menggunakan Quizizz dapat dijadikan sebagai bentuk assessment yang sesuai dengan kompetensi abad 21 yang meiliputi empat keterampilan tersebut. Selain itu, Quizizz juga akan semakin memudahkan guru dan juga peserta didik untuk memantau pembelajaran. Dengan Quizizz, guru akan terbantu dalam melakukan pensekoran ataupun perankingan. Selain itu fitur yang ada di dalam Quizizz juga dapat secara otomatis mengirinkan hasil belajar peserta didik kepada orangtau peserta melalui e-mail.

Keunggulan Quizizz sebagai alat assessment yang modern dan berbasis teknologi nyatanya juga tidak hanya sesuai dengan kompetensi abad 21 saja. Namun Quizizz juga mampu mengembangkan karakter yang ada di dalam diri peserta didik. Hasil temuan menunjukkan bahwa peserta didik mengalami peningkatan kepercayaan diri saat menggunakan Quizizz (Basuki \& Hidayati, 2019), selain itu Quizizz juga melatih kejujuran dan kemandirian bagi peserta didik. Sebab Quizizz sendiri dapat digunakan untuk meminimalisir kecurangan (Basuki \& Hidayati, 2019). Hal ini dikarenakan Quizizz sendiri memiliki model pertanyaan dan tipe jawaban yang acak, jadi hal ini meminimalisir kecurangan yang terjadi diantara peserta didik. Hal ini tentunya akan memupuk jiwa kejujuran, kemandirian, dan rasa percaya diri pada peserta didik. Hal ini tentunya juga sesuai dengan Kurikulum 2013 yang berfokus pada pendidikan karakter di Indonesia.

Merujuk pada hal-hal tersebut, maka Quizizz sebagai sebuah alat untuk melakukan penilaian atau assessment berbasis teknologi modern dapat dikaitkan dengan pembelajaran abad 21 yang memiliki keterampilan 4C, yaitu critical thinking skill, creative and innovative skill, communication skill, dan collaborative skill. \begin{tabular}{cccr}
\multicolumn{2}{c}{ Walaupun Quizizz } & sebagai & modern \\
assessment & memiliki & banyak & sekali \\
keunggulan & dalam & hal & penilaian
\end{tabular} pembelajaran, namun implikasi Quizizz juga menemui berbagai hambatan, terutama bagi negara-negara berkembang. Sebagai negara berkembang, Indonesia memiliki berbagai keterbatasan dalam hal mengembangkan pembelajaran yang berbasis teknologi modern. Hal ini dikarenakan pembelajaran yang menggunakan teknologi memiliki kecenderungan akses terhadap internet, sementara akses internet sendiri tidak dapat dirasakan di semua daerah yang ada di Indonesia. Hal ini sesuai dengan pernyataan dari Menkominfo yang menyatakan bahwa pembangunan akses internet yang ada di Indonesia memang belum merata (Laoli, 2019). Sementara dalam praktiknya sendiri Quizizz hanya dapat diakses secara online, sehingga membutuhkan akses pada internet.

Tidak meratanya akses pada internet, terutama di daerah pedesaan dan daerah $3 \mathrm{~T}$ Indonesia menyebabkan Quizizz akan sangat sulit untuk diaplikasikan. Selain itu untuk sekolah yang memiliki fasilitas terbatas dan tidak memiliki akses internet juga menjadi hambatan dalam penggunaan Quizizz sebagai alat assessmet yang sesuai diterapkan untuk pembelajaran abad 21. Tidak hanya akses terhadap internet yang tidak menjangkau semua daerah, namun masih banyaknya peserta didik yang belum memiliki smartphone (CNN Indonesia, 2020) ataupun perangkat pendukung yang dibutuhkan dalam Quizizz juga menjadi salah satu hambatan dan juga tantangan yang dihadapi oleh negara berkembang seperti Indonesia dalam mengaplikasikan assessment yang berbasis teknologi modern seperti Qizizz ini.

\section{SIMPULAN}

Pembelajaran abad 21 memungkinkan pembelajaran berbasis teknologi yang kini semakin berkembang pesat. Perkembangan teknologi tersebut mendorong adanya berbagai pengembangan, termasuk juga dalam bidang penilaian atau assessment. Jika sebelumnya penilaian konvensional masih menggunakan kertas, namun kini penilaian modern dapat memanfaatkan adanya teknologi. Quizizz merupakan salah satu alat 
dalam assessment modern yang berbasis teknologi yang dapat dimanfaatkan guru untuk melakukan evaluasi pembelajaran. Studi ini mengkaji Quizizz sebagai modern assessment yang dikaitkan dengan pembelajaran abad 21. Temuan menyimpulkan bahwa Quizizz juga memuat keterampilan-keterampilan abad 21, yang meliputi critical thinking skill, creative and innovative skill, communication skill, dan collaborative skill. Quizizz memberikan banyak dampak positif bagi pembelajaran, terutama bagi peningkatan motivasi peserta didik, dimana motivasi itu sendiri dapat meningkatkan keterampilan berpikir kritis (critical thinking skill) dan keterampilan kreativitas (creativity). Selain itu Quizizz juga dapat diintegrasikan dengan google classroom, sehingga dalam hal ini Quizizz juga berperan dalam meningkatkan keterampilan komunikasi (communication skill) dan kolaborasi (collaboration skill) peserta didik. Selain sangat sesuai dengan pembelajaran abad 21, Quizizz juga sesuai untuk mengembangkan karakter dari peserta didik, sebab Quizizz melatih peserta didik untuk bersikap jujur dan dapat melakukan penilaian diri secara individu. Namun penggunaan Quizizz ini tentunya menemui beberapa hambatan terlebih lagi di negara berkembang seperti Indonesia, sebab Quizizz sendiri menuntut akses terhadap internet, namun di Indonesia sendiri tidak semua daerah terjangkau oleh internet, terutama pada daerah 3T.

Penelitian ini memiliki batasan, dimana peneliti masih melakukan tahap awal dengan menggunakan metode literature review, sehingga di masa depan diharapkan penelitian ini dapat dilanjutkan pada tahap penelitian selanjutnya. Selain itu agar penggunaan Quizizz sebagai modern assessment dapat dimaksimalkan, maka pemerintah harus mampu menydiakan layanan internet yang dapat menjangkau seluruh kawasan yang ada di Indonesia.

\section{DAFTAR RUJUKAN}

Acedo, C., \& Hughes, C. (2014). Principles for learning and competences in the 21 st-century curriculum. Prospects, 44(4), 503-525. https://doi.org/10.1007/s11125-0149330-1

Aşıksoy, G., \& Sorakin, Y. (2018). The effects of clicker-aided flipped classroom model on learning achievement, Physics anxiety and students' perceptions. International Online Journal of Education and Teaching (IOJET), 5(2), 334-346. http://iojet.org/index.php/IOJET/articl e/view/389/238

Basuki, Y., \& Hidayati, Y. (2019). Kahoot! or Quizizz: the Students' Perspectives. July. https://doi.org/10.4108/eai.27-42019.2285331

Binkley, M., Erstad, O., Herman, J., Raizen, S., Ripley, M., Miller-Ricci, M., \& Rumble, M. (2014). Defining twenty-first century skills. In Assessment and teaching of 21 st century skills (pp. 17-66). Springer Netherlands.

https://doi.org/10.1007/978-94-0072324-5_2

Cadieux Bolden, D., Hurt, J., \& Richardson, M. K. (2017). Implementing Digital Tools to Support Student Questioning Abilities: A Collaborative Action Research Report. I.E.: Inquiry in Education, 9(1).

Chaiyo, Y., \& Nokham, R. (2017). The effect of Kahoot, Quizizz and Google Forms on the student's perception in the classrooms response system. 2nd Joint International Conference on Digital Arts, Media and Technology 2017: Digital Economy for Sustainable Growth, ICDAMT 2017, 178-182. https://doi.org/10.1109/ICDAMT.201 7.7904957

CNN Indonesia. (2020). Tak Semua Murid Punya Gadget, Belajar dari Rumah Terkendala. https://www.cnnindonesia.com/nasion al/20200317155848-20-484252/taksemua-murid-punya-gadget-belajardari-rumah-terkendala

Dinni, H. N. (2018). HOTS ( High Order Thinking Skills ) dan Kaitannya dengan Kemampuan Literasi Matematika. Prisma, 1, 170-176. 
Heroza, R. I., Putra, P., Rifai, A., Novianti, H., Nuriza, M. F., Ariefin, E. P., \& Rafly, M. (2020). Pelatihan Penggunaan LMS Sebagai Upaya Pengembangan Metode Pembelajaran Pada MGMP Bahasa Indonesia SMP Kab. Ogan Ilir. Annual Research Seminar (ARS), 5(2), 25-27. http://seminar.ilkom.unsri.ac.id/index. php/ars/article/view/2100

Hoidn, S. (2016). The Pedagogical Concept of Student-Centred Learning in the Context of European Higher Education Reforms. European Scientific Journal, ESJ, 12(28), 439. https://doi.org/10.19044/esj.2016.v12 n28p439

Howard, L. W., Tang, T. L. P., \& Jill Austin, M. (2015). Teaching Critical Thinking Skills: Ability, Motivation, Intervention, and the Pygmalion Effect. Journal of Business Ethics, 128(1), 133-147. https://doi.org/10.1007/s10551-0142084-0

Jukes, I., \& Dosaj, A. (2006). Understanding Digital Children (DKs): Teaching \& Learning in the New Digital Landscape. The InfoSavvy Group, June, 1-67. http://jayneturner.pbworks.com/w/file/ fetch/28960161/growingupdigit.pdf

Kristiani, K. D., Mayasari, T., \& Kurniadi, E. (2017). Pengaruh Pembelajaran STEM-PjBL terhadap Keterampilan Berpikir Kreatif. Prosiding SNPF (Seminar Nasional Pendidikan Fisika), 21, 266-274. http://ejournal.unipma.ac.id/index.php/snpf/a rticle/view/1719

Laoli, N. (2019). Menkominfo akui pembangunan jaringan internet di Indonesia belum merata. https://regional.kontan.co.id/news/me nkominfo-akui-pembangunanjaringan-internet-di-indonesia-belummerata

Mac Namara, D., \& Murphy, L. (2017). Online versus offline perspectives on gamified learning. CEUR Workshop Proceedings, 1857(September), 4752.

Miller, M. (2016). Game show classroom:
Comparing Kahoot!, Quizizz, Quizlet

Live and Gimkit - Ditch That

Textbook.

https://ditchthattextbook.com/gameshow-classroom-comparing-kahootquizizz-quizlet-live-and-quizalize/

Orhan Göksün, D., \& Gürsoy, G. (2019). Comparing success and engagement in gamified learning experiences via Kahoot and Quizizz. Computers and Education, 135, 15-29.

https://doi.org/10.1016/j.compedu.201 9.02.015

Prensky, M. (2001). Digital Natives, Digital Immigrants Part 1. On the Horizon, 9(5), 1-6. https://doi.org/10.1108/107481201104 24816

Rahayu, I. S. D., \& Purnawarman, P. (2019, July 12). The Use of Quizizz in Improving Students' Grammar Understanding through SelfAssessment. https://doi.org/10.2991/conaplin18.2019.21

Riantoni, C., \& Nurrahman, A. (2020). ANALISIS TINGKAT HUBUNGAN KARAKTER JUJUR SISWA TERHADAP HASIL BELAJAR IPA TERPADU. JPE (Jurnal Pendidikan Edutama, 7(2), 1-8.

http://ejurnal.ikippgribojonegoro.ac.id /index.php/JPE

Rodriguez, C. M. (2009). TheImpactofAcademicSelfConcept...TheCaseofBusinessStud.pdf . Higher Education Research and Development, 5(28), 523-539. https://doi.org/10.1080/072943609031 46841

Teo, P. (2016). Exploring the dialogic space in teaching: A study of teacher talk in the pre-university classroom in Singapore. Teaching and Teacher Education, 56, 47-60. https://doi.org/10.1016/j.tate.2016.01. 019

Teo, P. (2019). Teaching for the 21st century: A case for dialogic pedagogy. In Learning, Culture and Social Interaction (Vol. 21, pp. 170-178). Elsevier Ltd. https://doi.org/10.1016/j.lcsi.2019.03. 
009

Wahyudi, W., Rufiana, I. S., \& Nurhidayah, D. A. (2020). Quizizz: Alternatif Penilaian di Masa Pandemi Covid-19. Jurnal Ilmiah Soulmath : Jurnal Edukasi Pendidikan Matematika, 8(2), 95.

https://doi.org/10.25139/smj.v8i2.306 2

Yuni, E., Dwi, W. ; Sudjimat, A., \& Nyoto, A. (2016). Transformasi Pendidikan Abad 21 Sebagai Tuntunan Pengembangan Sumber Daya Manusia Di Era Global (Vol. 1).
Zhao, F. (2019). Using quizizz to integrate fun multiplayer activity in the accounting classroom. International Journal of Higher Education, 8(1), 37-43. https://doi.org/10.5430/ijhe.v8n1p37 Zubaidah, S. (2018). Mengenal 4C: Learning and Innovation Skills untuk Menghadapi Era Revolusi Industri 4.0 1 Simas eric learning model View project Education material View project.

https://www.researchgate.net/publicati on/332469989 
24 JURNAL PENDIDIKAN EDUTAMA, Vol. 8, No. 1 Januari, 2021 